\title{
K personální etice
}

\section{Zuzana Svobodová}

Envigogika 10 (4) - Recenzované články/ Reviewed Papers

Publikováno/Published dne 5. 12. 2015

DOI: $\underline{10.14712 / 18023061.501}$

\begin{abstract}
Abstrakt
V textu nazvaném „K personální etice" jsou postupně otevírány následující otázky: Co je základem etiky? Co zakládá lidství člověka? Jak se v dějinách proměnil pohled na podstatu člověka? Co znamenal objev subjekt-objektového př́stupu k světu? Proč se dnes hovoří o potřebě nové etiky? Po zdůraznění role komunikace v lidském bytí je ukázán důsledek rozdílu společenského nebo individuálního východiska lidské existence. Dále je vylíčeno postupné objevování personální dimenze člověka až k napětí, které je možné na základě Lévinasovy formulace vyjádřit jako otázku: nominativ, nebo akuzativ? Poukazem na upřednostnění akuzativního "sebe" před nominativním "já" se dospívá k upřednostnění odpovědnosti a péče jako (existenciálně) podstatnému etickému východisku pro smysluplný rozvoj člověka a světa.
\end{abstract}

\section{Klíčová slova}

etika; komunikace; ctnost; řád; osoba; vztahovost; odpovědnost; integrita

\begin{abstract}
:
In the text entitled "The Ethics of Persona" are successively opened following questions: What is the basis of ethics? What constitutes the humanity of man? How have views of human nature in history changed? What has the discovery of the subject-object approach to the world meant? Why do we now talk about the need for a new ethics? After emphasizing the role of communication in the human being, a consequence of the difference of social or individual bases of human existence is shown. Also depicted is the gradual discovery of the personal dimension of man and the tension, which can be expressed following Levinas's formulation, as a question: nominative, or accusative? Referring to the prioritisation of accusative "selves" before the nominative "Ego" leads to the prioritisation of responsibility and care as the (existential) significant ethical basis for the meaningful development of man and the world.
\end{abstract}

\section{Key words}

ethics; communications; virtue; order; person; relationality; responsibility; integrity 


\section{Komunikace jako základ etiky}

Pro Aristotela je celek nutně určující pro část, nebot' celek je vždy víc než cást, proto předtím, než začne $v$ díle Velká etika pojednávat o etických otázkách, uvažuje, čeho je etika částí. Záhy ukazuje, že má na mysli otázky týkající se lidského jednání, přičemž za nejlepší možnost lidského soužití považuje Aristotelés život $v$ poLIs - $v$ obci - a podstatným úkolem člověka vidí schopnost jednat politicky (jako občan). Jednat politicky mu pak znamená jednat zdatně, to jest dle ctnosti, řádně. Nikdo dle Aristotela nemůže jednat politicky bez ctnosti (ARETÉ). To znamená, má-li někdo jednat v zájmu obce, musí být jeho povaha raádná. Aristotelovi se jeví jako správný název pro nauku o řádném jednání politika, spiše než etika. To, co se zabývá řádným jednáním, tedy etika, je nicméně východiskem politické nauky - nauky o tom, jak žít řádně jako občan ve společenství obce. Vše toto pramení z Aristotelova pohledu na přirozenost člověka. Člověk je Aristotelovi bytostí nadanou možností sdílet názory na př́ijemné a nepř́ijemné - ve smyslu posuzování př́ijemného a nepříjemného - a na základě toho utvářet společenství, obec, POLIs, kterou určuje společný ÉTos, řád. Řády jednotlivých společenství utvářených lidmi se vzájemně liší - čím je to způsobeno? Řád pramení ze zvyku: Tak je také možné vyložit jednu ze zásadních vět pro toho, kdo má zájem porozumět původu samotného termínu "etika" dle Aristotela - nalezneme ji ve Velké etice: "Slovo éthos má jméno od ethos (zvyk); ,etická' se totiž nazývá proto, že se jí nabývá zvykáním (ethizesthai)." (Magna moralia 1186a - v řečtině název díla ÉTHIKÓN MEGALóN) ${ }^{1}$ Etika měla název pro Řeky ÉTHIKÉ, stejný termín je uveden i ve výše uvedeném výroku na místě českého „etická". Rozdílné zvyky a tradice jsou tedy pramenem vzájemně odlišných řádů (ÉTos).

Člověk tedy má řeč užívat $k$ tomu, aby sděloval, co je mu milé a co nemilé. Řeč je tedy darem, ale zároveň úkolem daným člověku. I kdyby člověk tento svůj úkol neplnil, přesto jej komunikativnost předchází, podobně, jako jej předchází obec (podle oné logiky, kdy celek je více než část). Komunikace zakládá možnost bytí člověka: Člověk přichází na svět skrze komunikaci a jeho komunikativní srostitost (konkrétnost, z latinského concrescere - srůstat) v lůně matky je podmínkou jeho prvního vývoje. Proto také zkoumání jazyka může otevř́t oblast reflexe našeho bytí ve světě a naší existence. ${ }^{2}$ Člověk se $v$ komunikaci nachází dříve, než se pro ni rozhodl. Tuto skutečnost, kterou naléhavě připomínají někteří myslitelé personalistické filosofie 20. století, nacházíme odhalenou již u Aristotela. Tento základní poznatek je klíčový i pro vidění světa jako komunikujícího kosmu, kdy sice ne všemu jedinec rozumí, ne všechno je člověk schopen chápat, pochopit a uchopit, ale nese jej řád, který Řekové nazývali kosmos, protože věřili, že tento komunikující řád je harmonický, souladný, což v řeckém poznání znamenalo především to, že různosti jsou schopné vytvářet jeden dobrý a krásný celek ( $\mathrm{i}$ "kosmetika" má název od této skutečnosti). Tento řád má být člověkem poznán a udržován, proto teprve je-li jedinec též dostatečně raádný, získal-li dostatečně zvykem a cvikem zdatnost, může jednat obci prospěšně, politicky.

Tam, kde je přirozenost člověka vztažena $k$ životu $v$ řádu, $v$ obci, kde je člověk pojímán jako vždy již vrozen do komunikace, celku, řádu, tam je předpokládáno bratrství lidí jako východisko, nikoli jako něco, k čemu se člověk rozhoduje. Toto všeobecné, univerzální bratrství je pak základem, východiskem, smyslem veškerého lidského konání. Naopak

\footnotetext{
${ }^{1}$ Cit. dle českého překladu: ARISTOTELÉS. Magna moralia. 1. vyd. Praha: Petr Rezek, 2005, 178 s. ISBN 8086027228.

2 Srov. VAŇKOVÁ, Irena. Nádoba plná řeči: (člověk, řeč a přirozený svět). Vyd. 1. Praha: Karolinum, 2007, 312 s. ISBN 978-80-246-1122-8. S. 41.
} 
v těch tradicích, kde se zakládá společenství na smlouvě, kterou mezi sebou ze svého rozhodnutí uzavírají svobodní jedinci (kontraktualismus ${ }^{3}$ ), je východiskem a smyslem lidského konání zájem člověka. Rozdíl v praxi těchto dvou východisek může být někdy nepostřehnutelný, někdy obrovský. Dotýkáme se zde základů politických stanovisek.

Vrat́me se však k etice. Etika je tedy od řecké filosofické tradice hledáním nejlepšího možného (sou)žití, rozumí se řádného žití ve společnosti, politicky. Co v takové etice hledáme? Je to př́kaz, návod? Nebo smysl života? U Platóna Ize číst otázku, zda má odborník jednat podle př́kazů a návodů, nebo i jinak. Odpovědí je, podobně jako u Aristotela, že jedná-li se o skutečného odborníka, pak je zapotřebí, aby nejen znal všechny předpisy a návody, ale též, aby byl schopen jednat i jinak - přičemž se argumentuje, že je to nutné $\checkmark$ konkrétních problematických situacích, ale též pro rozvoj vědy. ${ }^{4}$ Komunikace tedy vytváři prostředí, $v$ němž se rozvijí lidský život, to vyžaduje aktivitu. Lidství znamená aktivitu $v$ kon-taktu, souladu, $v$ harmonii s životním prostředím, kosmem, univerzem. Být dobře člověkem, totiž být lidsky, znamená aktivně se podílet na vytváření dobrého spoluobčanství ve světě, žít zdatně (dle ARETÉ - ctnosti) pospolu ve společnosti. Podle Aristotela nejde o rozvíjení vrozených předpokladů, zde se od svého učitele, Platóna, žák odklonil. Aristotelovi je počátkem či východiskem lidského jednání dobrovolná rozumová úvaha. ${ }^{5}$ Platónovi je počátkem lidského jednání nahlédnutí idejí ústrojím, kterým člověk nabývá poznání. Zatímco ostatní ctnosti vnímá Platón jako ty, které nejprve $v$ duši nejsou, až teprve později jsou do ní vštěpovány zvykem a cvičením (tedy shodně jako později Aristotelés), ctnost rozumového poznání - tedy ctnost onoho ústrojí - náleží podle Platóna jinému řádu, dle jeho slov "božštějšímu", nebot' přísluší k tomu, co své schopnosti nikdy neztrácí, ale podle toho, na co nahlíží ( $k$ čemu je obrácena, k čemu směřuje), stává se užitečnou, nebo naopak škodlivou. ${ }^{6}$ Zde má tedy rozhodující roli výchova, jejímž cílem má být otáčení onoho ústrojí směrem $\mathrm{k}$ dobru jako nejvyšší ideji. Aristotelés však měl možnost navazovat na pozdního Platóna, kdy Platón sám své dílo reviduje, není tedy nutné vidět tento rozpor jako zcela zásadní. To, co totiž Aristotelés vyvodí jako základní, totiž pojem pohybu jako změny, pohyb duše, PSYCHÉ7, tedy pohyblivost živého jako takového, která se liší od mechanického pohybu, bude pro výchovu člověka neméně inspirující - jako Platónovo úsilí otáčet ústrojím poznání. Aristotelés považoval duši za absolutní vlastnost každé jednotlivosti, je to nitro jako pohyb, který se stává vnitřním zrakem i znakem, umožňujícím přechod mezi "ještě ne" $a$ "již ne", tedy mezi nerealitami, je to změna sama, jí je podřazen i mechanický pohyb, který je relací, stavem, vnějším vztahem bez vztahu k vnitřku. ${ }^{8}$

\footnotetext{
${ }^{3}$ Srov. SOUSEDÍK, Stanislav. Svoboda a lidská práva: jejich přirozenoprávní základ : esej. Vyd. 1. Praha: Vyšehrad, 2010, 131 s. ISBN 978-80-7429-036-7. S. 88.

${ }^{4}$ Srov. PLATÓN. Politikos. 4., opr. vyd. Praha: OIKOYMENH, 2005, 95 s. ISBN 8072981595. 299e: „Je zřejmé, že by nám všechna umění docela zahynula a že by ani později neožila vinou tohoto zákona, zabraňujícího bádání; tím by se život, který je i nyní těžký, stával na onen čas naprosto nesnesitelným." 300c: "skutečný politik se bude ř́dit ve své činnosti namnoze svým uměním, nic se nestaraje o písemné rády"

${ }^{5}$ Srov. ARISTOTELÉS. Magna moralia. 1187b 15-20.

${ }^{6}$ Srov. PLATÓN. Ústava. 5., opr. vyd. Praha: OIKOYMENH, 2014, 427 s. ISBN $9788072985043.518 c-$ 519.

${ }^{7}$ Srov. ARISTOTELÉS. O duši. 2. nezm. vyd. Praha: P. Rezek, 1995, 297 s., [1] př́l. na vol. listu. ISBN 8090179649. S. 29 (403b 29-30).

8 Srov. PATOČKA, Jan. Aristoteles, jeho předchůdci a dědicové: studie z dějin filosofie od Aristotela $k$ Hegelovi. 1. vyd. Praha: Nakladatelství Československé akademie věd, 1964, s. 316.
} 


\section{Rozpad univerza a hledání nové komunikace, nové etiky}

V 17. století se pohyb jako změna, pohyb duše, vnímá jako něco teoreticky přímo škodlivého, naopak mechanický pohyb je považován za základ všeho, dokonce i tradičního pojmu duše, čímž byla zahájena nejen cesta k mechanické psychologii. ${ }^{9}$

Objevem subjektu, který se liší od všeho ve světě tím, že je schopen si svou myslí myslet, objektivně chápat, představovat předměty, tedy Descartovým objevem struktury já jako ego-cogito-cogitatum (personální moment - subjektivní průběh - předmět), sice člověk vnímá sebe jako chápajícího, zároveň však vyděleného ze světa. (Tato vydělenost tedy opak srostitosti - je počátek neudržitelného rozvoje.) Předmět není zcela uchopitelný, dokud jej vnímáme jako věc o sobě, ale až poté, když se jej chápeme jako objektu, předmětu, jako věci před námi. Tím nadlouho zavládl statický pohled na věci. První průlom do tohoto statického pochopení vědomí učinil až Hegel pojetím dialektického pohybu. Otevřel tím cestu k chápání pohybu jako základu veškeré ontologie, k otázkám po prameni, vnitřní dynamice i ústí pohybu, po vztahu k pojmu dění a stavu. Jan Patočka odkazoval současným myslitelům pokračovat v promýšlení dynamiky pohybu: „Je úkolem dneška na troskách koncepcí německé klasické filosofie vybudovat skutečně takové asubjektivní pojetí pohybu a dění, kterému by pohyb byl opět - jako kdysi u Aristotela - tím, co buduje vnitřně samo jsoucno věcí, nikoli pouhou změnou na povrchu, nedotýkající se podstaty, a co dovoluje pochopit v jednotě bez abstraktnosti a násilí zároveň to nejelementárnější i nejvyšší, př́rodu i člověka a společnost." 10 Termín „asubjektivní" užíval Patočka pro vyjádření opaku k subjekt-objektovému přístupu descartovského člověka. Zároveň však tímto termínem chtěl uchovat důraz na personální dimenzi lidství.

Otázku po podstatě si kladli již první filosofové, velmi záhy se vytváří termín HYPOKEIMENON, který měl značit substrát, to, z čeho dané žije. Jan Patočka zhodnocuje tuto teorii jako předaristotelskou konstrukci vedoucí k "filosofii věci" ${ }^{11}$, k zpředmětňování, objektivizování i živé prírody. HyPOKEIMENON se překládalo jako substance, ale s tím, že se nejedná o něco k uchopení, ale o to, co zakládá možnost našeho uchopování, podstata. ${ }^{12}$ Dnes si uvědomujeme, že pokud hledáme základ živoucího, pak jej nelze vidět neměnně mrtvolný, každá podstata živoucího je vydána pobývání, k účasti živoucího života; v takovém životním prostředí každá podstata trvá tak, že se časuje. ${ }^{13}$ Chceme-li žít a tvořit v životním prostředí, pak je nám třeba jiného nazírání než Descartova rozvrhu subjekt - objekt (já pozorující - ono pozorované), v němž je vždy již předpokládána jasnost vědomí (clare et distincte), kde subjekt pouze verifikuje a je zaměřen na rekonstrukci svého vědění. Descartes je objevitelem personální dimenze, ale ta byla dále využívána k odkazu na předmětnost našeho vnímání, totiž že vždy vnímáme něco (cogitatum). Pozdější britská tradice empiriků převedla Descartem objevené ego cogito na cogitatum, depersonalizovala

\footnotetext{
${ }^{9}$ Patočka zde odkazuje např. na podíl Gassendiho pro psychologii a Hobbese a Locka pro společenské vědy vůbec. Právě Gassendi však vůbec neporozuměl Descartovu významu cogito, když mu namítá, že mohl užít i odkazu na jinou aktivitu, např.: „ambulo, ergo sum" (chodím, tedy jsem). Srov. tamtéž, s. 317.

10 Tamtéž, s. 325.

${ }^{11}$ PATOČKA, Jan. Tělo, společenství, jazyk, svět: ze záznamů přednášek proslovených ve školním roce 1968-69 na filosofické fakultě University Karlovy. 1. vyd. Praha: Institut pro středoevropskou kulturu a politiku, Oikúmené, 1995. ISBN 8085241900. S. 20.

12 Tamtéž, s. 17.

13 PALOUŠ, Radim, SVOBOdovÁ, Zuzana. Homo educandus: filosofické základy teorie výchovy. Vyd.

1. Praha: Karolinum, 2011. ISBN 9788024619019. S. 110.
} 
ego na soubor jistých cogitata, do struktury cogitata, tak vznikl impersonalistický subjektivismus, jindy Patočkou nazývaný též empirický impersonalismus. ${ }^{14}$

Ani PSYCHÉ $v$ antické tradici nebyla vnímána jako subjekt, ale jako životní energie, životní funkce, impersonálně, ve třetí osobě. $V$ antické filosofii subjektivita nebyla, jsoucno bylo vždy ono, substanciální. Naopak cogito, ergo sum, Ize jako myšlenku vyslovit jen $\checkmark$ první osobě, tak novověká filosofie objevila personalitu člověka. Descartovo úsilí vrátit člověku jeho panující roli ve světě bylo téměř vyplněno. Jen s tím rozdílem, že skutečný panovník (jako dřive u Platóna "skutečný odborník"), ovládající svou roli, byl ale vždy také zároveň skutečným správcem - starajícím se a spravujícím, pečujícím, nikoli jen mistrujícím, jak to viděl Descartes. ${ }^{15}$

U Kanta je vyzdvižen personální charakter prožívání více než u Descarta - Kant, i když sám nemá důvěru $v$ empirickou metodu, přebírá na jedné straně $z$ empirické tradice to, že subjekt je vystaven proudu dojmů, naše vnímání je receptivní, ale zároveň klade nový důraz na aktivitu vědomí (autonomní já), náš subjekt má vlastní fundus instructus (ustrojený podklad), jímž je forma poznání strukturami prostoru a času; tak je u Kanta vyzdvižena aktivita a autonomie lidského poznání; to je tradice personalistického kriticismu. ${ }^{16}$

Etika je Kantovi vědou o zákonech svobody, nazývanou také mravouka a náleží $k$ materiální filosofii (vedle fyziky, vědy o zákonech přírody, která se nazývá také přírodovědou a je též materiální filosofí, narozdíl od logiky, která je filosofií formální). Protože Kant usiluje načrtnout čisté, apriorní (podle principu, formy), předzkušenostní poznání, uvažuje též na jedné straně o empirické složce etiky a na straně druhé o čisté složce etiky - Ize je nazývat praktickou antropologií (empirická složka etiky) a morálkou (formální, principielní složka etiky). ${ }^{17}$ Kant rozlišil praktická pravidla (založená na zkušenosti) a morální zákony (zákony dané člověku z čistého rozumu apriori). Zatímco praktická pravidla jsou namnoze antropocentrická, $v$ Kantově rozvrhu by morální zákony byly prosté všech lidských pohnutek, jednání by bylo motivováno jen svobodnou, dobrovolnou úctou k zákonu. ${ }^{18}$ Pouze jednání z povinnosti, z príkazu (DEON), má morální obsah (nikoli pouhé jednání z náklonnosti, byt́ v souladu s povinností); tak je dle Kanta člověk odpovědný zákonu, a to dř́ve než čemukoli jinému. ${ }^{19}$

\section{Persona: na cestě k osobní odpovědnosti (závěr)}

Kant svým kritickým př́stupem umožnil (znovu)odkrytí odpovědnosti, která předchází intenci - (osobnímu) záměru, což souvisí s již dříve zmíněným pohledem na člověka jako bytost, která je ve světě (ve společenství) dřive, než jedinec jako individuum, které

\footnotetext{
${ }^{14}$ Srov. PATOČKA, Jan. Tělo, společenství, jazyk, svět. S. 22, 23.

${ }^{15}$ Srov. DESCARTES, R. Discours de la méthode (Rozprava o metodě, 1637), 6. část, Bibliothèque de la Pléiade, Éd. Gallimard, 1966, s. 168. V českém překladu DESCARTES, R. Rozprava o metodě. Praha: Svoboda, 1992. VI, 2, s. 45.

${ }^{16}$ Srov. tamtéž.

${ }^{17}$ KANT, Immanuel. Základy metafyziky mravů. 1. vyd. Praha: Svoboda, 1976. S. 9-10.

18 Tamtéž, s. 30, 32, 35.

19 Tamtéž, s. 29.
} 
samo sebe prosazuje. Člověk je dříve na světě, jako pobývající ze vztahů a ve vztazích, než sám pro sebe. Svět je podmínkou žití jedince.

Toto zdůraznění interpersonálního charakteru lidského bytí umožnilo překročit od člověkostředné (antropocentrické) etiky k etice (jež je někdy nazývána ekoetikou či holistickou etikou), $v$ níž je člověk a jeho jednání posuzováno $z$ hlediska širší skutečnosti, $\checkmark$ niž se člověk jako rozumná a komunikace schopná bytost vždy již nachází vyzván k odpovědnému bytí, k bytí, které může a má odpovídat a hledat mezi možnostmi náležité způsoby jednání, kterými utváří svůj charakter směrem k naplňování lidskosti, kterými jako persona hraje dobře svou roli $v$ divadle světa. Člověk je svým ustrojením $v$ možnosti přebírat a ovládat lidskou roli, stávat se záměrně osobou, která spoluutváří svůj charakter, jehož existování je záměrné a tudíz též za něj nese odpovědnost. Má-li být aktivní vycházení do světa autonomní tvorbou skutečně lidské, $v$ dialogu $s$ prostředím, pak by měla persona, jako bytost nadaná rozumem a svobodnou vưlí, odpovídat přes (zásadní) váhání k rozhodnutí a volbě. ${ }^{20}$

Skutečnost, že naše komunikace ve světě je antropologická, by neměla znamenat, že bude též antropocentrická. Jacques Maritain hovořil v tomto kontextu o integrálním humanismu ${ }^{21}$, papež František hovoří o integrálním a integrujícím př̌stupu ${ }^{22}$. Ekoetika je spojena ve svých počátcích právě s myšlenkou znovuuvědomování si naší konkrétnosti (srostitosti), s potřebou nového porozumění pro integrující př́stupy, s viděním potřeby spolupodílet se na odpovědném bytí v celku světa. Osobnost, persona, je s integritou jednající bytost (snad proto, že se zde dotýkáme jádra či nitra osobnosti, hovoří se o vnitřní integritě). Jak důležité je pochopit a vychovávat sebe i nám svěřené v intenci této integrity ukazuje i nedávný článek v časopise Envigogika. ${ }^{23}$

Člověk je schopen odstupu od sebe sama, zralý člověk je (zřejmě výjimečně mezi ostatními živými tvory) schopen posuzovat své vlastní jednání v kontextu světa a je nadán schopností volit si způsoby jednání ve světě, způsoby svého existování - vycházení od svého sebe. Emmanuel Lévinas, který promýšlel personální charakter člověka, vyjádřil rozdíl mezi antropocentrickým pojetím a pojetím personalistickým rozdílem vycházení do světa ve formě $v$ nominativu (já), nebo ve formě akuzativní (sebe) ${ }^{24}$. Prosazující se já užívá subjekt-objektového prístupu ve světě a tedy čehokoli $i$ kohokoli se chápe, to zpředmětňuje, činí objektem vhodným k manipulaci. Naopak akuzativní forma je vycházením do světa s posláním vydat se ve službě, ve starosti ${ }^{25}$, péči 26 , a v tomto smyslu učinit

${ }^{20}$ Srov. RIC氏EUR, Paul. Filosofie vůle. I, Fenomenologie svobody. Vyd. 1. Praha: OIKOYMENH, 2001.

527 s. Knihovna novověké tradice a současnosti; sv. 34. ISBN 80-7298-033-5. S. 148.

${ }^{21}$ MARITAIN, Jacques. Křestáanský humanismus: [Humanisme intégral]. Vyd. 1. V Praze: Universum, 1947, 310 s. Člověk a společnost (Universum). S. 102.

22 Papež František. Encyklika Laudato si. Dotupné na WWW:

http://www.radiovaticana.cz/clanek.php4?id=22034. [2015-11-03] Zejména 4. kapitola.

${ }^{23}$ Envigogika 10 (2), DOI: 10.14712/18023061.458.

${ }^{24}$ Srov. LÉVINAS, Emmanuel. Etika a nekonečno. 1. vyd. Praha: Institut pro středoevropskou kulturu a politiku, 1994, 197 s. Oikúmené. ISBN 80-85241-67-6. S. 104. Lze vnímat též jako jistou kritiku stanoviska vyjádřeného in: ROSENZWEIG, F. Der Mensch und sein Werk. Gesammelte Schriften, Haag 1976-79, Dordrecht-Boston-Lancaster 1983-84, svazek II. S. 208.

${ }^{25}$ Srov. HEIDEGGER, Martin. Bytí a čas. 1. vyd. Praha: Oikoymenh, 1996, 477 s. Oikúmené. ISBN 8086-005-12-7. S. 445 ( $§ 80)$.

${ }^{26}$ Srov. PLATÓN. Ústava. 3. opr. vyd. Praha: OIKOYMENH, 2001, 359 s. Knihovna antické tradice. ISBN 80-7298-024-6. S. 219 (520b). 
své možnosti skutečností, proměnit svou potenci ve smysluplnou obět ${ }^{27}$. Který z přístupů se spolupodílí na smysluplném rozvoji a v kterém člověk ztrácí svůj charakter, svou lidskost, by úsudku schopnému člověku mělo být zjevné. Zbývá oslovit svobodnou vůli k činu.

\section{Literatura}

- $\quad$ Aristotelés, (2005). Magna moralia. 1. vyd. Praha: P. Rezek.

- $\quad$ Aristotelés, (1995). O duši. 2. nezm. vyd. Praha: P. Rezek.

- Descartes, R. (1966). Discours de la méthode (Rozprava o metodě, 1637). Éd. Gallimard: Bibliothèque de la Pléiade.

- Descartes, R. (1992). Rozprava o metodě. Praha: Svoboda.

- Wals, A., Brody, M., Dillon, J., \& Stevenson, R. B. (2015). Propojení př́rodovědného a environmentálního vzdělávání. Envigogika, 10(2), 10-14712. Retrieved from http://www.envigogika.cuni.cz/index.php/Envigogika/article/view/458 http://dx.doi.org/10.14712/18023061.458

- Heidegger, M. (1996). Bytí a čas. 1. vyd. Praha: Oikúmené.

- Kant, I. (1976). Základy metafyziky mravů. 1. vyd. Praha: Svoboda.

- Lévinas, E. (1994). Etika a nekonečno 1. vyd. Praha: Institut pro středoevropskou kulturu a politiku. Oikúmené.

- Maritain, J. (1947). Křestáanský humanismus: [Humanisme intégral]. 1. vyd. Praha: Universum. Člověk a společnost (Universum).

- Palouš, R., \& Svobodová, Z. (2011). Homo educandus: Filosofické základy teorie výchovy. Vyd. 1. Praha: Karolinum.

- Papež František (2015). Encyklika Laudato si. Retrieved from http://www.radiovaticana.cz/clanek.php4?id=22034

- Patočka, J. (1964). Aristoteles, jeho předchưdci a dědicové: Studie z dějin filosofie od Aristotela k Hegelovi. 1. vyd. Praha: Nakladatelství Československé akademie věd.

- Patočka, J. (2006). Češi II. Sebrané spisy Jana Patočky. Sv. 13. Praha: OIKOYMENH.

- Patočka, J. (1995). Tělo, společenství, jazyk, svět: Ze záznamů přednášek proslovených ve školním roce 1968-69 na filosofické fakultě University Karlovy. 1. vyd. Praha: Institut pro středoevropskou kulturu a politiku, Oikúmené.

27 PATOČKA, Jan. Češi II. Sebrané spisy Jana Patočky. Sv. 13. Praha: OIKOYMENH, 2006. ISBN 807298-182-X. S. 407-408. Jan Patočka je př́kladem osobnosti, která dorostla do této role odpovědnosti. 
- Platón, (2005). Politikos. 4., opr. vyd. Praha: OIKOYMENH.

- Platón, (2001). Ústava. 3. opr. vyd. Praha: OIKOYMENH. Knihovna antické tradice.

- Ricœur, P. (2001). Filosofie vůle. I, Fenomenologie svobody. Vyd. 1. Praha: OIKOYMENH. Knihovna novověké tradice a současnosti; sv. 34.

- $\quad$ Rosenzweig, F. (1984). Der Mensch und sein Werk. Gesammelte Schriften, svazek II. Dordrecht-Boston-Lancaster: Dordrecht-Boston-Lancaster.

- Sousedík, S. (2010). Svoboda a lidská práva: Jejich přirozenoprávní základ: esej. vyd. 1. Praha: Vyšehrad.

- Vaňková, I. (2007). Nádoba plná řeči: (člověk, řeč a přirozený svět). Vyd. 1. Praha: Karolinum. 